\title{
INTERVENSI BIMBINGAN BELAJAR PADA TRYOUT INTERNA TERHADAP HASIL UJI KOMPETENSI MAHASISWA PRODI D - III KEBIDANAN
}

\section{INTERVENTION OF LEARNING GUIDANCE IN INTERNAL TRY OUT TO COMPETENCY TEST RESULTS OF D - III MIDWIFERY STUDENTS IN MIDWIFERY DEPARTMENT}

\author{
Baiq Yuni Fitri Hamidiyanti, Intan Gumilang Pratiwi \\ Politeknik Kesehatan Kemenkes Mataram, Indonesia \\ Korespondensi : intangumil@gmail.com
}

\begin{abstract}
Competency test is a method for evaluating the cognitive, affective and psychomotor abilities of health professionals. The level of graduation of an educational institution's competency test is one of the parameters to assess the level of efficiency and effectiveness of the teaching and learning process at the institution. This study aims to determine the effect of tutoring on internal tryouts on student competency test results. The research design is a quasiexperimental used in this study is the nonequivalent control group design. The research sample of Midwifery D-III Study Program students in semester VI totaled 53 people. Analysis of differences using Mann Whitney. The study was conducted in October - November 2019. The results showed the results (1). The analysis of mann-whitney $U$ shows that $p=0.036<\alpha$ 0.05 shows that there is a significant relationship between the learning method with the guidance of the group buzz with the passing level of potential test (2). The results of the mann whitney test obtained a value of $U=0,000<\alpha 0.05$ that there is a relationship between independent learning with the results of the potential test. (3) the GPA with the competency test value of mann whitney $p=0,000<\alpha 0,005$ shows that there is a relationship between the GPA and the potential test. The conclusion of the study there is a relationship between the provision of group business guidance, independent study guidance and GPA on the results of student competency tests.
\end{abstract}

Keywords: Intervention, Tutoring and Competency Test

\begin{abstract}
ABSTRAK
Uji kompetensi merupakan metode untuk mengevaluasi kemampuan kognitif, afektif dan psikomotor tenaga profesi kesehatan. Tingkat kelulusan uji kompetensi suatu institusi pendidikan merupakan salah satu parameter untuk menilai tingkat efisen dan efektifitas proses belajar mengajar di institusi. Penelitian ini bertujuan untuk mengetahui pengaruh bimbingan belajar pada tryout interna terhadap hasil uji kompetensi mahasiswa. Desain penelitian adalah quasi eksperimen yang digunakan dalam penelitian ini adalah nonequivalent control group design. Sampel penelitian mahasiswa Prodi D-III Kebidanan pada semester VI berjumlah 53 orang. Analisis perbedaan menggunakan Mann Whitney. Penelitian dilaksanakan pada Oktober - November 2019. Hasil penelitian menunjukkan hasil (1). Analisis mann-whitney $U$ menunjukkan $\mathrm{p}=0,036<\alpha 0,05$ menunjukkan terdapat hubungan signifikan antara metode pembelajaran dengan bimbingan buzz grup dengan tingkat kelulusan uji kompotensi (2). Hasil uji mann whitney diperoleh nilai $U=0,000<\alpha 0,05$ bahwa terdapat hubungan antara belajar mandiri dengan hasil uji kompotensi. (3) IPK dengan uji kompetensi nilai mann whitney $\mathrm{p}=0,000<\alpha 0,005$ ini menunjukkan bahwa ada hubungan antara IPK
\end{abstract}


dengan uji kompotensi. Kesimpulan penelitian terdapat hubungan antara pemberian bimbingan belajar buss grup, bimbingan belajar mandiri dan IPK terhadap hasil Uji Kompetensi mahasiswa.

\section{Kata Kunci: Intervensi, Bimbingan Belajar dan Uji Kompetensi}

\section{PENDAHULUAN}

Pendidikan bermutu merupakan suatu capaian pembelajaran yang diperoleh dalam proses pembelajaran, sehingga upaya untuk meningkatkan merupakan hal yang harus dilakukan dengan baik. Penjaminan mutu pendidikan bertujuan untuk melindungi masyarakat agar memperoleh layanan dari hasil pendidikan sesuai yang dijanjikan oleh penyelenggara pendidikan. Mutu pendidikan dipengaruhi oleh banyak faktor yaitu Mahasiswa, pengelolah pendidikan, lingkungan, kualitas pembelajaran, kurikulum, sarana prasarana dan pembiayaan (Fadhli M, 2017)

Uji kompetensi merupakan metode untuk mengevaluasi kemampuan kognitif, afektif dan psikomotor tenaga profesi kesehatan. Menurut Undang - Undang No 12 tahun 2012 pendidikan tinggi pasal 44 ayat 1 menyatakan bahwa Sertifikat kompetensi merupakan pengakuan kompetensi atas prestasi lulusan yang sesuai dengan keahlian dalam cabang ilmunya dan atau memiliki prestasi diluar program studinya, dan ayat 2 menyatakan bahwa sertifikat kompetensi bagaimana dimaksud pada ayat 1 diterbitkan oleh perguruan tinggi bekerja sama dengan organisasi profesi, lembaga pelatihan, atau lembaga sertifikasi yang terakreditasi kepada lulusan yang telah lulus uji kompetensi (Undang - undang RI, 2012)

Uji kompetensi bidan adalah upaya pemerintah di dukung organisasi IBI dan AIPKIND yang berdasar pada peraturan bersama antara Menteri Pendidikan dan Kebudayaan dan Menteri Kesehatan No. 3/VII/ PB/ 2004 dan 52/2014 tahun 2014 tentang penyelenggaraan Uji Kompetensi Mahasiswa Program Diploma III Kebidanan (DIKTI, 2016)

Secara nasional dengan menguji pengetahuan dan keterampilan sebagai dasar dalam menjalankan profesionalisme dalam pelayanan. Uji Kompetensi tersebut melibatkan suatu proses untuk mengukur pengetahuan, keterampilan dan sikap tenaga kesehatan sesuai dengan standar profesi atau dalam arti lain uji kompetensi diharapkan menjadi media untuk meningkatkan kualitas tenaga kesehatan secara berkala (Kemenristek, 2018).

Uji kompetensi bidan di Indonesia baru mulai dilaksanakan sejak tahun 2013 dan hasil rata-rata $30 \%$ peserta tidak lulus uji kompetensi bidan dengan nilai batas lulus 40,14 \%. Daftar peserta uji 
kompetensi bidan dari periode 2017 sampai periode 2018 mengalami penurunan adalah sebagai berikut 33.792 peserta pada periode IX/2017, 19.957 periode X/2018 dan 13.146 peserta pada periode XI/2018. Tingkat kelulusan rata-rata periode masih rendah yaitu $55 \%$ tingkat kelulusan dan tingkat kelulusan rendah sangat terlihat pada periode uji kompetensi bidan saat retaker ikut sebagai peserta ujian yaitu periode VIII/2017 adalah 22,89 \% dan periode $\mathrm{X} / 2018$ adalah 27,95 \% (Kemenristekdikti, 2018) .

Tingkat kelulusan uji kompetensi suatu institusi pendidikan merupakan salah satu parameter untuk menilai tingkat efisen dan efektifitas proses belajar mengajar di institusi. Bagi perguruan tinggi uji kompetesi akan menjadi acuan untuk menunjukkan prestasi belajar, sedangkan bagi pemerintah uji kompetensi menjadi acuan untuk perbaikan kualitas pendidikan terkait sarana prasarana dan SDM. Kelulusan uji kompetensi merupakan pencerminan dari usaha belajar, semakin baik usaha belajar seorang mahasiswa semakin baik pula hasil belajar yang diperolehnya (Hakimzadeh, 2013).

Neng Kurniati (2013), melakukan penelitian terhadap 176 mahasiswa, yang hasilnya ada hubungan yang signifikan antara peran pembimbing akademik dengan motivasi belajar mahasiswa. Dan menurut hasil penelitian Tri sunarsih (2010) ada hubungan yang bermakna antara motivasi belajar, kemandirian belajar dan bimbingan akademik terhadap hasil prestasi belajar.

$$
\text { Mengingat pentingnya Uji }
$$

Kompetensi yang merata dan terstandarisasi secara nasional untuk menjamin kompetensi para lulusannya dalam menjalankan tugas profesi maka perlu ditinjau lebih jauh kesiapan institusi pendidikan dalam mempersiapkan para calon bidan untuk menghadapi uji kompetensi. Pencapaian kelulusan uji kompetensi dipengaruhi oleh berbagai faktor, baik faktor internal maupun faktor eksternal. Berdasar atas hasil studi pendahuluan yang dilakukan di Prodi D III Kebidanan Jurusan Kebidanan Poltekkes Kemenkes Mataram bahwa uji kompetensi first taker (pengambilan pertama) Diploma III Kebidanan tahun 2016 diikuti oleh 90 orang peserta dengan presentase kelulusan 97,8\%. Uji kompetensi di tahun 2017 diikuti oleh 72 orang peserta dengan presentase kelulusan 97,3\%. Uji kompetensi di tahun 2018 diikuti oleh 41 orang peserta dengan presentase kelulusan $87,2 \%$.

Penelitian ini bertujuan untuk mengetahui pengaruh bimbingan belajar pada tryout interna terhadap hasil uji 
kompetensi mahasiswa Prodi D - III Kebidanan Jurusan Kebidanan Poltekkes Kemenkes Mataram.

\section{METODE}

Desain penelitian adalah quasi eksperimen yang digunakan dalam penelitian ini adalah nonequivalent control group design. Kedua kelompok dalam proses pembelajaran mendapatkan perlakuan sama dari segi tujuan dan isi materi pelajaran. Perbedaan digunakan pembelajaran metode diskusi (buss grup) pada kelompok intervensi dan pada kelompok kontrol menggunakan pembelajaran konvensional. Sampel penelitian mahasiswa Prodi D-III Kebidanan pada semester VI berjumlah 53 orang. Instumen penelitian menggunakan lembar kuesioner. Analisis perbedaan menggunakan Mann Whitney. Penelitian dilaksanakan pada Oktober - November 2019

\section{HASIL DAN PEMBAHASAN}

Tabel 1 : Distribusi responden berdasarkan karakteristik umur pada mahasiswa Prodi D III Kebidanan Poltekkes Mataram

\begin{tabular}{crc}
\hline Umur (tahun) & n & \% \\
\hline 20 & 13 & 24,5 \\
21 & 23 & 43,4 \\
22 & 12 & 22,6 \\
23 & 5 & 9,4 \\
\hline Jumlah & $\mathbf{5 3}$ & $\mathbf{1 0 0 , 0}$ \\
\hline
\end{tabular}

Tabel 2 : Distribusi responden berdasarkan uji kompetensi responden pada mahasiswa Prodi D - III Kebidanan Poltekkes Kemenkes Mataram

\begin{tabular}{ccc}
\hline Uji kompetensi & n & \% \\
\hline Tidak Lulus & 4 & 7,5 \\
Lulus & 49 & 92,5 \\
\hline Jumlah & $\mathbf{5 3}$ & $\mathbf{1 0 0 , 0}$ \\
\hline
\end{tabular}

Tabel 3 : Distribusi responden berdasarkan buzz grup responden pada mahasiswa Prodi D - III Kebidanan Poltekkes Kemenkes Mataram

\begin{tabular}{lcc}
\hline Buzz grup & n & \% \\
\hline Kurang & 5 & 18,5 \\
Cukup & 22 & 81,5 \\
\hline Jumlah & $\mathbf{2 7}$ & $\mathbf{1 0 0 , 0}$ \\
\hline
\end{tabular}

Tabel 4 : Distribusi responden berdasarkan pembimbingan responden pada mahasiswa Prodi D - III Kebidanan Poltekkes

Kemenkes Mataram

\begin{tabular}{ccc}
\hline Perlakuan & n & \% \\
\hline Dibimbing & 27 & 50,9 \\
Mandiri & 26 & 49,1 \\
\hline Jumlah & $\mathbf{5 3}$ & $\mathbf{1 0 0 , 0}$ \\
\hline
\end{tabular}

Tabel 5: Distribusi responden berdasarkan crosstab antara uji buzz group dengan kompetensi pada mahasiswa Prodi D - III Kebidanan Poltekkes Kemenkes Mataram 


\begin{tabular}{|c|c|c|c|c|c|c|}
\hline \multirow{3}{*}{ Buzz grup } & \multicolumn{4}{|c|}{ Uji kompetensi } & \multicolumn{2}{|c|}{$\Sigma$} \\
\hline & \multicolumn{2}{|c|}{ Lulus } & \multicolumn{2}{|c|}{ Tidak lulus } & & \\
\hline & $\mathbf{n}$ & $\%$ & $\mathbf{n}$ & $\%$ & $\mathbf{n}$ & $\%$ \\
\hline Kurang & 4 & 80 & 1 & 20 & 5 & 100 \\
\hline Cukup & 22 & 100 & 0 & 0 & 22 & 100 \\
\hline Jumlah & 26 & 96,3 & 1 & 3,7 & 27 & 100 \\
\hline \multirow{2}{*}{ Perlakuan } & \multicolumn{2}{|c|}{ Lulus } & \multicolumn{2}{|c|}{ Tidak lulus } & \multicolumn{2}{|c|}{$\Sigma$} \\
\hline & $\mathbf{n}$ & $\%$ & $\mathbf{n}$ & $\%$ & $\mathbf{n}$ & $\%$ \\
\hline Dibimbing & 26 & 96,3 & 1 & 3,7 & 27 & 100 \\
\hline Mandiri & 23 & 88,5 & 3 & 11,5 & 26 & 100 \\
\hline Jumlah & 49 & 92,5 & 4 & 7,5 & 53 & 100 \\
\hline \multirow[t]{2}{*}{ IPK } & lulus & \multicolumn{2}{|c|}{$\begin{array}{c}\text { Tidak } \\
\text { Lulus }\end{array}$} & & $\Sigma$ & \\
\hline & $\mathbf{n}$ & $\%$ & $\mathbf{n}$ & $\%$ & $\mathbf{n}$ & $\%$ \\
\hline$\geq 3,00$ & 49 & 92,5 & 4 & 7,5 & 53 & 100 \\
\hline$<3,00$ & 0 & 0 & 0 & 0 & 0 & 0 \\
\hline Jumlah & 49 & 92,5 & 4 & 7,5 & 53 & 100 \\
\hline
\end{tabular}

Tabel 6 : Distribusi responden berdasarkan buzz grup, dengan uji kompotensi dengan pada mahasiswa Prodi D - III Kebidanan

Poltekkes Kemenkes Mataram

\begin{tabular}{lccccc}
\hline $\begin{array}{c}\text { Metode } \\
\text { penilaian }\end{array}$ & \multicolumn{2}{c}{ Mean rank } & \multicolumn{2}{c}{ Sum of ranks } & $\begin{array}{c}\text { Mann } \\
\text { whitney }\end{array}$ \\
\cline { 2 - 6 } & Lulus & $\begin{array}{c}\text { Tidak } \\
\text { lulus }\end{array}$ & Lulus & $\begin{array}{c}\text { Tidak } \\
\text { lulus }\end{array}$ & \\
\hline Buss grup & 14,42 & 3,00 & 375,00 & 3,00 & 0,036 \\
Mandiri & 13,50 & 13,50 & 310,50 & 40,50 & 0,000 \\
IPK & 27,00 & 27,00 & 1323,00 & 108,00 & 0,000 \\
\hline
\end{tabular}

Berdasarkan tabel. 5 didapatkan hasil menunjukkan bahwa responden yang menyatakan cukup dengan metode pembelajaran dengan buzz grup secara keseluruhan $100 \%$ lulus uji kompetensi. Pada proses pembimbingan $26(96,3 \%)$ lulus uji kompetensi dan $1(3,7 \%)$ tidak lulus uji kompetensi, sedangkan responden yang melakukan belajar mandiri $23(88,5 \%)$ lulus uji kompetensi dan terdapat $3(11,5 \%)$ tidak lulus uji kompetensi. Berdasarkan
IPK $\geq 3,00$ lulus uji kompotansi 49 $(92,5 \%)$ dan tidak lulus $4 \quad(7,5 \%)$. Efiktifitas proses pembelajaran dengan menggunakan metode buzz group pada mahasiswa yang memilih untuk belajar mandiri lebih banyak yang tidak lulus uji kompetensi yaitu 3 (11,5\%).

Berdasarkan Tabel 6 didapat didapat hasil analisis mann-whitney $U$ menunjukkan $\mathrm{p}=0,036<\alpha 0,05$ menunjukkan terdapat hubungan signifikan antara metode pembelajaran dengan bimbingan buzz grup dengan tingkat kelulusan uji kompotensi atau hubungan yang positif artinya "dengan menggunakan metode bimbingan belajar maka peluang untuk lulus uji kompotensi akan sangat besar".

Metode Buzz Group yaitu cara pembahasan suatu masalah yang pelaksanaannya warga belajar dibagi dalam kelompok kecil antara tiga sampai enam orang membahas suatu masalah yang diakhiri dengan penyampaian hasil pembahasannya oleh setiap juru bicara ${ }^{(19)}$. Metode Buzz Group memiliki kelebihan yaitu semua peserta dipaksa oleh situasi untuk menyampaikan pendapatnya, menumbuhkan suasana akrab dan menyenangkan serta dapat menghimpun berbagai pendapat dalam waktu singkat ${ }^{(16)}$. Diskusi mendorong peserta untuk 
menemukan solusi dan mengembangkan kemampuan berpikir kritis. Kekurangan metode ini yaitu dapat terjadi pengelompokan yang tidak seimbang di mana ada kelompok yang terdiri atas peserta yang tidak tahu apaapa ataupun sebaliknya, laporan kelompok-kelompok kecil tidak tersusun secara sistematis, serta pembicaraan mungkin berbelit-belit. Metode ini tepat untuk pembelajaran lanjutan tentang konsep-konsep yang telah dipelajari sebelumnya dan untuk memecahkan masalah yang dihadapi bersama dalam kehidupan (Sudjana, 2010) .

Seorang bidan untuk memenuhi apa yang menjadi tuntutan masyarakat maka proses uji kompetensi perlu dilalui untuk mengukur apakah dia telah dianggap cakap dan mampu untuk melaksanakan pelayanan yang baik dan profesional. Hubungan dengan proses pembelajaran yang baik salah satunya adalah dengan menggunakan metode pembelajaran buzz group, hipotesis yang dipergunakan adalah dengan metode pembelajaran tersebut maka diharapkan tingkat kelulusan pada uji kompetensi juga akan semakin baik.

Akademi Kebidanan merupakan salah satu Program Studi yang menerapkan strategi pembelajaran dengan metode ceramah, diskusi dan simulasi, karena proses perkuliahan di Akademi Kebidanan memanfaatkan $40 \%$ pertemuan di kelas untuk teori dan $60 \%$ praktik. $60 \%$ praktik klinik dilakukan di laboratorium dan di lapangan. Sebelum diaplikasikan langsung terhadap klien, mahasiswa melatih keterampilan di laboratorium. Praktik klinik di laboratorium dilakukan dengan metode simulasi. Pada proses belajar mengajar di Akademi Kebidanan, praktik laboratorium mahasiswa dilakukan setelah mereka mendapatkan pemahaman Asuhan Kebidanan secara teori terlebih dahulu (Sofyan, 2011) .

Hasil penelitian sejalan dengan penelitian Hidayati dkk (2019) Intervensi Penyuluhan dengan Metode Ceramah dan Buzz untuk Peningkatkan Pengetahuan dan Sikap Kader Posyandu dalam Pengendalian Rabies di Kabupaten Sukabumi yaitu sampel terdiri atas 87 kader posyandu penelitian dilaksanakan dengan mengintervensi 43 kader menggunakan metode ceramah dan mengintervensi 44 kader menggunakan metode buzz group. Hasil penelitian menunjukkan bahwa terdapat perbedaan yang nyata antara skor pre-test dan post-test pada kelompok ceramah (pengetahuan $(\mathrm{p}=0,000)$, sikap $(\mathrm{p}=0,000))$ maupun kelompok buzz group (pengetahuan $(\mathrm{p}=0,004)$, sikap $(\mathrm{p}=0,001))$. Metode ceramah dan metode buzz group 
tidak berbeda nyata dalam meningkatkan pengetahuan dan sikap kader ( $p>0,05)$.

Hasil penelitian yang diperoleh Sarwoko (2009) yaitu hubungan metode buzz group terhadap pencapaian hasil ujian asuhan kebidanan I dengan metode Objektive Structure Clinical Assesment (OSCA) pada Mahasiswa Akademi Kebidanan Estu Utomo Boyolali jalur umum semester II tahun 2009. Sampel dipilih dari mahasiswa Akademi Kebidanan Estu Utomo Boyolali 47 mahasiswa dari kelas A metode buzz group dan 48 kelas B metode konvensional. Hasil penelitian menunjukkan metode pembelajaran buzz group mampu menghasilkan nilai pengetahuan dan ketrampilan asuhan kebidanan I mahasiswa yang lebih tinggi daripada metode konvensional $(b=9.55 ; \mathrm{p}=$ 0.007 untuk pengetahuan; $b=8.20 ; \mathrm{p}=$ 0.000 untuk ketrampilan).

Berdasarkan tabel 6.2 didapatkan hasil hasil uji mann whitney diperoleh nilai $\mathrm{U}=0,000<\alpha 0,05$ hal tersebut dapat disimpulkan bahwa terdapat hubungan antara belajar mandiri dengan hasil uji kompotensi. Hubungan tersebut dapat dijelaskan sebagai hubungan yang negative artinya adalah dengan belajar mandiri untuk menghadapi uji kompetensi maka peluang untuk lulus uji kompetensi semakin kecil.
Hasil penelitian ini diibaratkan sebagai bentuk dua mata pisau ; satu sisi diharapkan dengan kemandirian dalam belajar kepada mahasiswa diharapkan mereka mempunyai tanggung jawab dalam mengatur dan mendisiplinkan dirinya dan dapat mengembangkan kemampuan belajar atas kemauan sendiri. Pada sisi yang lain terdapat kelemahan pada proses belajar mandiri diantaranya kurangnya pengawasan dari tenaga pengajar, kurang terfokus pada pelajaran, arah dari pembejaran kurang, serta tidak ada kontrol untuk dapat tercapainya tujuan dari pembelajaran sehingga kelemahan-kelemahan tersebut yang dapat menjadi penyebab kurangnya tingkat kelulusan ukom pada mahasiswa.

Hasil penelitian sesuai dengan penelitian yang dilakukan oleh Suardana I.K (2012) Implementasi Model Belajar Mandiri Untuk Meningkatkan Aktivitas, Hasil dan Kemandirian Belajar Mahasiswa diperoleh dari 34 orang mahasiswa Jurusan Pendidikan Fisika FMIPA, penelitian dilaksanakan dalam dua siklus pembelajaran hasil penelitian adalah: aktivitas belajar mandiri mahasiswa untuk kategori baik meningkat sebesar 9,8\%; hasil belajar mahasiswa dengan nilai $\mathrm{A}$ dan $\mathrm{B}$ meningkat sebesar 47,1\%; dan kemandirian belajar mahasiswa dengan kualifikasi tinggi 
dan sangat tinggi meningkat sebesar 29,4\%, masing- masing dari siklus 1 ke siklus 2.

Hasil penelitian ini sesuai dengan hasil yang diperoleh oleh Meliansari (2017) Hasil penelitian menunjukkan bahwa terdapat hubungan positif antara belajar mandiri (X1) dengan hasil belajar PKN $(\mathrm{X} 1 \mathrm{dan} \mathrm{Y}=0.685)$.

Pembelajaran mandiri merupakan proses pembelajaran yang menuntut peserta didik menjadi subyek yang harus merancang, mengatur dan mengontrol kegiatan mereka sendiri secara bertanggung jawab. Hal ini bertolak belakang dengan prinsip pembelajaran yang disebut sebagai teacher-directed learning. Namun demikian, institusi pendidikan tetap bertanggung jawab sepenuhnya, baik secara teknis, fisik, dan moral, terhadap seluruh program pendidikan yang ditawarkan kepada para peserta didik.

Pembelajaran mandiri memerlukan negosiasi dalam perancangan pembelajaran secara keseluruhan. Perancangan pembelajaran ini merupakan alat yang fleksibel tetapi efektif untuk membantu peserta didik dalam penentuan tujuan belajar secara individual. Tanggung jawab peserta didik dan pengajar harus dibuat secara eksplisit dalam perancangan pembelajaran. Partisipasi para peserta didik dalam penentuan tujuan belajar akan membuat mereka menjadi committed terhadap proses pembelajaran.

Berdasarkan tabel 6.3 didapatkan hasil penelitian menunjukkan bahwa IPK dengan nilai mann whitney $\mathrm{p}=0,000<\alpha$ 0,005 ini menunjukkan bahwa ada hubungan antara IPK dengan uji kompotensi.

Prestasi belajar adalah hasil usaha dari semua kegiatan yang dilakukan mahasiswa, baik dari belajar, pengalaman, dan latihan dari suatu kegiatan. Untuk mengetahui hasil belajar maka dibuatlah suatu alat uklur tes prestasi (achievement test). Nilai tes ini diatur menurut rangking dan diformulasikan dalam bentuk indeks prestasi. Ukuran kemampuan mahasiswa dalam menyelesaikan sebuah kurikulum dan predikat kelulusannya dinyatakan dengan Indeks Prestasi Kumulatif (IPK).

Hasil penelitian ini sejalan dengan penelitian yang dilakukan oleh Nurhayati, 2007, bahwa terdapat hubungan yang bermakna antara nilai IPK dengan tingkat kelulusan uji kompetensi yaitu nilai $\mathrm{P}=$ 0,001. Hasil penelitian lain yang mendukung yaitu Fields dkk menyatakan terdapat hubungan antara IPK mahasiswa tahun ketiga dengan United States Medical License Examination

(USMLE). Kulatunga-Moruzi dan Norman juga berpendapat adanya korelasi yang 
signifikan antara Licentiate Medical Council of Canada (LMCC) dengan IPK program sarjana kedokteran dan sarjana kebidanan, mereka juga mengatakan IPK merupakan prediktor terbaik untuk menentukan hasil ujian kognitif.Selain itu juga ditemukan adanya hubungan OSCE dengan USMLE .

Tetapi meskipun uji standar kompetensi tiap negeri mempunyai landasan ideologi yang sama, teknis pelaksanaanya sangat berbeda, hasil temuan tersebut belum tentu dapat diaplikasikan di Indonesia. Penelitian ini dimaksudkan untuk mengkaji hubungan IPK program studi pendidikan bidan dengan nilai hasil UKBI. Membawa harapan hasil temuan yang didapatkan dapat membantu instansi pendidikan dalam menyingkapi masalah yang ada.

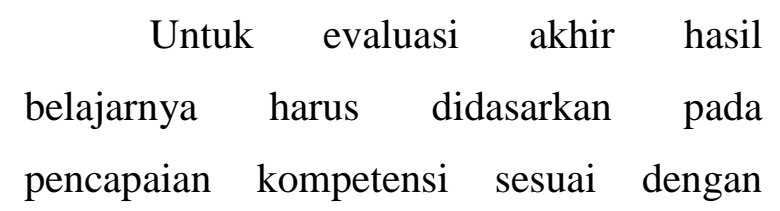
Standar Kompetensi Bidan. Pencapaian kompetensi tersebut dinilai dengan menggunakan Penilaian Acuan Patokan (Criterion-referenced). Kriteria kelulusan itu sendiri merupakan hasil pencapaian kompetensi dan penilaian proses pendidikan (akademik dan non-akademik) dan harus memenuhi asas validitas, reliabilitas, kelayakan dan mendorong proses belajar (Maltzer, 2008).

\section{SIMPULAN}

Terdapat hubungan antara pemberian bimbingan belajar buss grup, bimbingan belajar mandiri dan IPK terhadap hasil Uji Kompetensi mahasiswa.

\section{DAFTAR PUSTAKA}

Badan Pengembangan dan Pemberdayaan Sumber Daya Manusia Kesehatan (BPPSDMK) (2016). Peran Institusi Pendidikan dalam Meningkatkan Kualitas Lulusan yang Kompeten melalui Uji Kompetensi. Pusat Standarisasi, Sertifikasi dan Pendidikan Berkelanjutan SDM Kesehatan.

Fadhli M (2017). Manajemen Peningkatan Mutu Pendidikan. Jurnal Studi Manajemen Pendidikan, Vol. 1, No. 02. Hal 216 - 240.

Hakimzadeh, R.e.a. (2013) "The teaching learning in nursing education," GSE Journal of Education pp. 174-84.

Hidyati dkk (2019). Intervensi Penyuluhan dengan Metode Ceramah dan Buzz untuk Peningkatkan Pengetahuan dan Sikap Kader Posyandu dalam Pengendalian Rabies di Kabupaten Sukabumi. Jurnal Penyuluhan, Maret 2019 Vol. 15 No. 1. Hal 65 - 74.

Ibrahim, Nurdin (2013) Hubungan Antara Belajar Mandiri Dan Motivasi Berprestasi Dengan Hasil Belajar Pendidikan Agama Islam Di SMP Terbuka, UIN Alaudin

Kemenristek DIKTI (2016). Implementasi Uji Kompetensi Nasional bidang Kesehatan sebagai Langkah Konkrit Penjaminan Mutu Pendidikan Tinggi Kesehatan. Retrivied 24 Maret 2017. Melalui: http://www.dikti.go.id 
Kementerian Riset Teknologi dan Pendidikan Tinggi (Kemenristedikti) (2018). Data Statistis Tingkat Kelulusan Uji Kompetensi Bidan.

Kurikulum Inti Pendidikan Diploma III Kebidanan, (2016). Kementrian Kesehatan RI Badan Pengembangan Dan Pemberdayaan SDM Kesehatan Pusat Pendidikan Dan Pelatihan Tenaga Kesehatan.

Meltzer, D.E. 2008. The Relationship Between Mathematict Preparation and Conceptual Learning Gains in Physics: A Possible "Hidden Variable" in Diagnostic Pretes Score http://ojps.ajp.org/ajp/hotml[2/7/2008].d iakses pada tanggal 14 desember 2014

Notoatmodjo, S. (2016) Metode Penelitian Kesehatan. Jakarta : Rineka Cipta

Republik Indonesia. Undang- Undang No. 12 Tahun 2012 tentang Pendidikan Tinggi. Lembaran Negara Republik Indonesia Tahun 2012 Nomor 158. Sekretariat Negara. Jakarta. 2012.

Sarwoko, (2009), Pengaruh metode buzz group terhadap pencapaian hasil ujian asuhan kebidanan I dengan metode Objektive Structure Clinical Assesment (OSCA) pada Mahasiswa Akademi Kebidanan Estu Utomo Boyolali

Suardana I.K (2012). Implementasi Model Belajar Mandiri Untuk Meningkatkan Aktivitas, Hasil, Dan Kemandirian Belajar Mahasiswa. Jurnal Pendidikan dan Pengajaran, Jilid 45, Nomor 1, April 2012, hlm.56-65.

Wina Sanjaya,2006, meode bimbingan kelompok kecil (buzz grup).jakarta. pustaka. 